\title{
STUDIES ON THE RHENIUM COMPLEXES DERIVED FROM SUBSTITUTED THIAZOLE AND IMIDAZOLE LIGANDS
}

MD. MANZURUL KARIM,* SUDEEPTA SUTRADHAR AND KAMRUL HASSAN

Department of Chemistry, Jahangirnagar University,Savar Dhaka-1342, Bangladesh

\begin{abstract}
Treatment of $\left[\operatorname{Re}_{2}(\mathrm{CO})_{10}(\mathrm{MeCN})_{2}\right]$ with 2-(methylmercapto)benzothiazole/2(methylmercapto)benzimidazole in refluxing benzene resulted in the isolation of compounds $\left[\mathrm{Re}_{2}(\mathrm{CO})_{8}\left(\mu-\eta^{1}, \eta^{1}-\left(\mathrm{C}_{7} \mathrm{H}_{4} \mathrm{NS}\right) \mathrm{SCH}_{3}\right]\right.$ and $\left[\mathrm{Re}_{2}(\mathrm{CO})_{8}\left(\mu-\eta^{1}, \eta^{1}-\right.\right.$ $\left.\left(\mathrm{C}_{7} \mathrm{H}_{5} \mathrm{~N}_{2}\right) \mathrm{SCH}_{3}\right]$ in moderate yield. The compounds have been characterized by IR, ${ }^{1} \mathrm{H}$ NMR, ${ }^{13} \mathrm{C}$ NMR and mass spectral data.
\end{abstract}

\section{Introduction}

Nitrogen and sulfur containing heterocycles represent an important class of ligands in organometallic chemistry. ${ }^{1}$ Such ligands offer new possibilities for the preparation of bi and polynuclear metal complexes with potential application in catalysis. Binuclear complexes bridged by multidentate ligands have been the subject of considerable amount of work in the last two decades. ${ }^{2}$ Rhenium complexes of general formula $\left[(\mu-\mathrm{H}) \mathrm{Re}_{2}(\mu-\right.$ $\left.\mathrm{Y})(\mathrm{CO})_{8}\right]\left(\mathrm{Y}=\mathrm{PR}_{2},{ }^{3} \mathrm{Cl}, \mathrm{I}^{4}, \eta^{2}\right.$-pyridyl, $\left.{ }^{5} \eta^{2}-\mathrm{C} \equiv \mathrm{CR},{ }^{6} \eta^{2}-\mathrm{C}=\mathrm{CRR},{ }^{7} \mathrm{C}(\mathrm{R}) \mathrm{O},{ }^{8} \mathrm{SR}^{9}\right)$ are well known in recent organometallic chemistry papers. Considerable interest in this area and the reactivity of $\mathrm{N}$ and $\mathrm{S}$ containing heterocycles with transition metal carbonyls have grown because of the presence of more than one type of donor atoms in these ligands that can introduce novel reactivity and frequently stabilizes the metal cluster frame work by acting as bridging or chelating ligands. ${ }^{10}$

Over the last few years Kabir et al. have been investigating the oxidative addition reactions of a series of $\mathrm{N}$ and $\mathrm{S}$ containing heterocycles such as benzothiazole, ${ }^{11}$ thiomorpholine, ${ }^{11}$ thiazolidine, ${ }^{12} 4$-methyle thiazole, ${ }^{13}$ and thiazole ${ }^{14,15}$ with ruthenium and osmium carbonyls and observed a remarkable influence on the type of the products obtained depending on the carbonyls, the heterocyclic ligands as well as the reaction conditions.

For example, thiomorpholine $\mathrm{C}_{4} \mathrm{H}_{9} \mathrm{NS}$ reacts with $\left[\mathrm{Ru}_{3}(\mathrm{CO})_{12}\right]$ at $66^{\circ} \mathrm{C}$ to give $\left[\mathrm{Ru}_{3}\left(\mu-\eta^{2}-\right.\right.$ $\left.\mathrm{SCH}_{2} \mathrm{CH}_{2} \mathrm{NH}_{2}\right)(\mathrm{CO})_{9}$ ] by a ring opening reaction of the ligand followed by the elimination of a $\mathrm{C}_{2}$ fragment whereas under identical conditions thiazolidine, $\mathrm{C}_{3} \mathrm{H}_{7} \mathrm{NS}$, forms the dinuclear compound $\left[\mathrm{Ru}_{2}\left(\left(\mu-\eta^{2}-\mathrm{SCH}_{2} \mathrm{CH}_{2} \mathrm{NHCH}_{2}\right)(\mathrm{CO})_{6}\right]\right.$ followed by ring opening cleavage of the ligand as well as the rapture of the metal-metal bonds. (Scheme-1). ${ }^{12}$ 


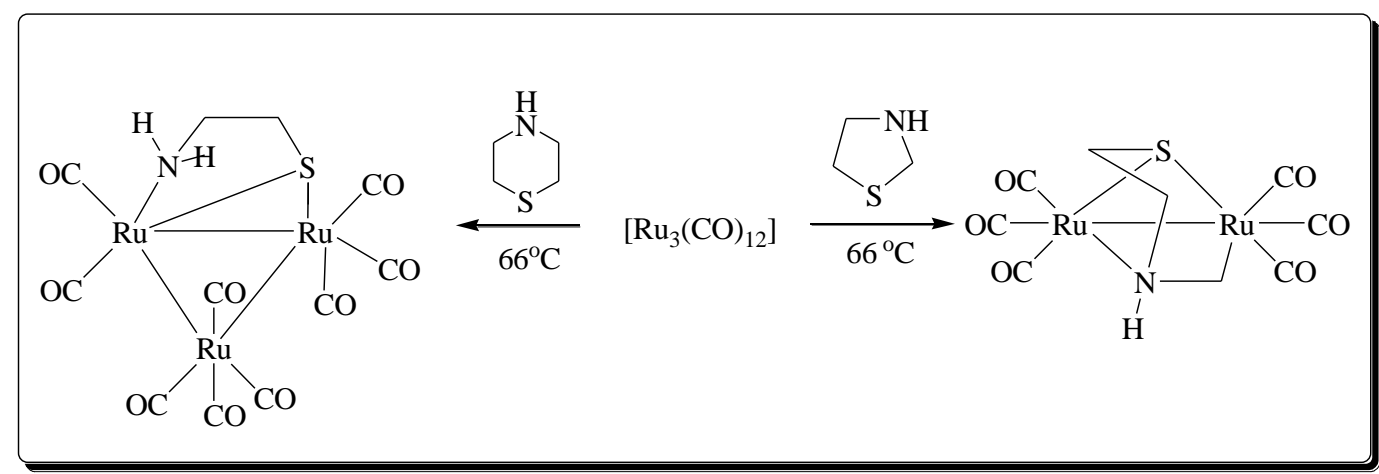

Scheme 1

The reaction of the labile cluster $\left[\mathrm{Os}_{3}(\mathrm{CO})_{10}(\mathrm{MeCN})_{2}\right]$ with thiazole gives two isomeric products, $\left[(\mu-\mathrm{H}) \mathrm{Os}_{3}(\mathrm{CO})_{10}\left(\mu-2,3-\eta^{2}-\mathrm{C}=\mathrm{N}-\mathrm{CH}=\mathrm{CHS}\right)\right] \mathbf{2 . 1}$ and $\left[(\mu-\mathrm{H}) \mathrm{Os}_{3}(\mathrm{CO})_{10}\left(\mu-3,4-\eta^{2}-\right.\right.$ $\mathrm{CH}=\mathrm{NC}=\mathrm{CHS}$ ) $\mathbf{2 . 2}$ in $20 \%$ and $60 \%$ respectively as shown in (Scheme-2) by ortho $\mathrm{C}-\mathrm{H}$ activation with respect to $\mathrm{N}$ atom. ${ }^{13}$

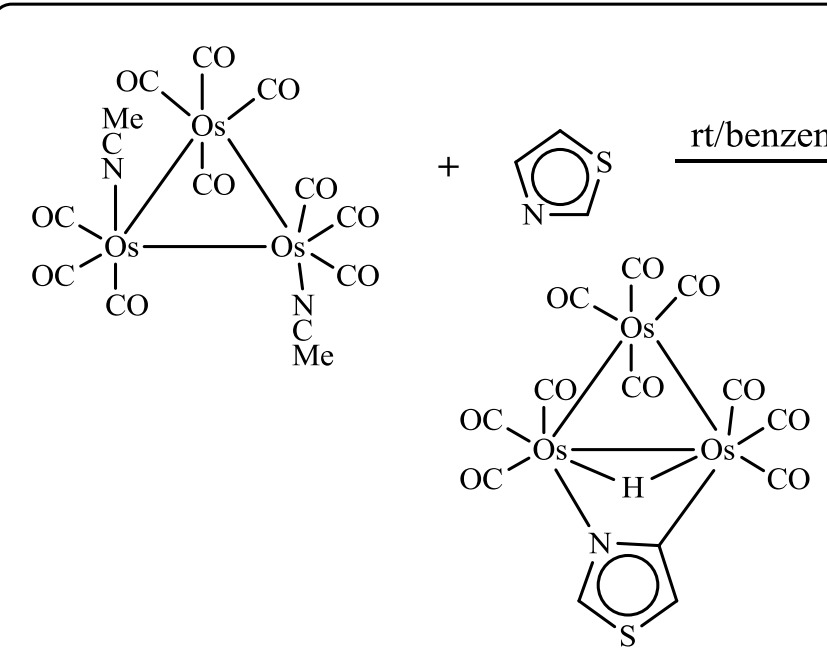

2.2

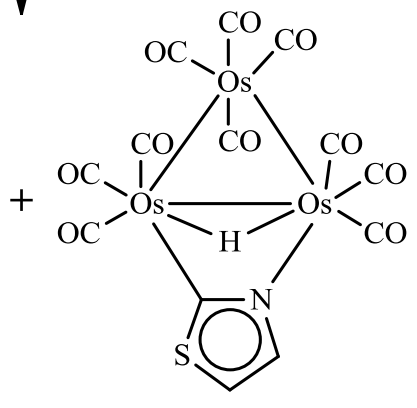

2.1

Scheme 2

Treatment of $\left[\operatorname{Re}_{2}(\mathrm{CO})_{8}(\mathrm{NCMe})_{2}\right]$ with five equivalents of thiazole and 4-methylthiazole in refluxing benzene gave two new sets of compounds $\left[(\mu-\mathrm{H}) \mathrm{Re}_{2}(\mathrm{CO})_{7} \mu-2,3-\eta^{2}-\mathrm{C}_{3} \mathrm{H}(4-\right.$ $\left.\mathrm{R}) \mathrm{NS})\left\{\eta^{1}-\mathrm{NC}_{3} \mathrm{H}_{2}(4-\mathrm{R}) \mathrm{S}\right\}\right]\left(\right.$ 3.1, $\left.\mathrm{R}=\mathrm{H}, \mathbf{3 . 2}, \mathrm{R}=\mathrm{CH}_{3}\right),\left[(\mu-\mathrm{H}) \mathrm{Re}_{2}(\mathrm{CO})_{6}\left\{\mu-2,3-\eta^{2}-\mathrm{C}_{3} \mathrm{H}(4-\right.\right.$ R)NS $\left.\}\left\{\eta^{1}-\mathrm{NC}_{3} \mathrm{H}_{2}(4-\mathrm{R}) \mathrm{S}\right\}_{2}\right]\left(\mathbf{3 . 3}, \mathrm{R}=\mathrm{H}, \mathbf{3 . 4}, \mathrm{R}=\mathrm{CH}_{3}\right)$ and $f a c$ - $\left[\mathrm{Re}(\mathrm{CO}){ }_{3}(\mathrm{Cl})-\left\{\eta^{1}-\mathrm{NC}_{3} \mathrm{H}_{2}(4-\right.\right.$ R)S) $\left.\}_{2}\right] .{ }^{14}\left(3.5, \mathrm{R}=\mathrm{H}, \mathbf{3 . 6}, \mathrm{R}=\mathrm{CH}_{3}\right)$ (Scheme-3). 


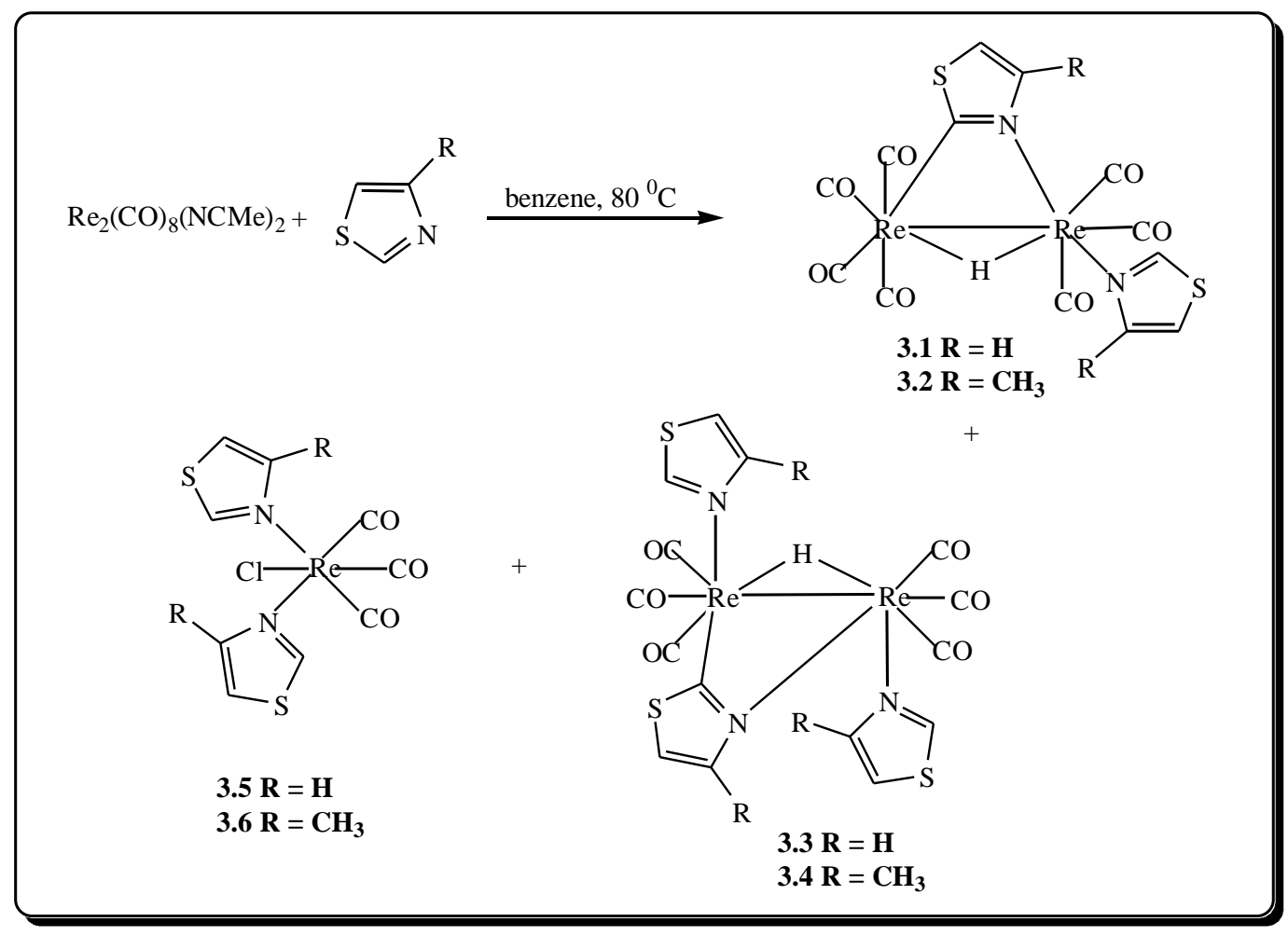

Scheme 3

Recently Azam et al. reported the reaction of $\left[\mathrm{Os}_{3}(\mathrm{CO})_{10}(\mathrm{NCMe})_{2}\right]$ with 4-methylthiazole and afforded a decacarbonyl compound $\left[(\mu-\mathrm{H}) \mathrm{Os}_{3}(\mathrm{CO})_{10}\left(\mu-2,3-\eta^{2}-\mathrm{C}=\mathrm{N}-\mathrm{CMe}=\mathrm{CHS}\right)\right] 4$ (Scheme 4) in a moderately high yield. ${ }^{15}$

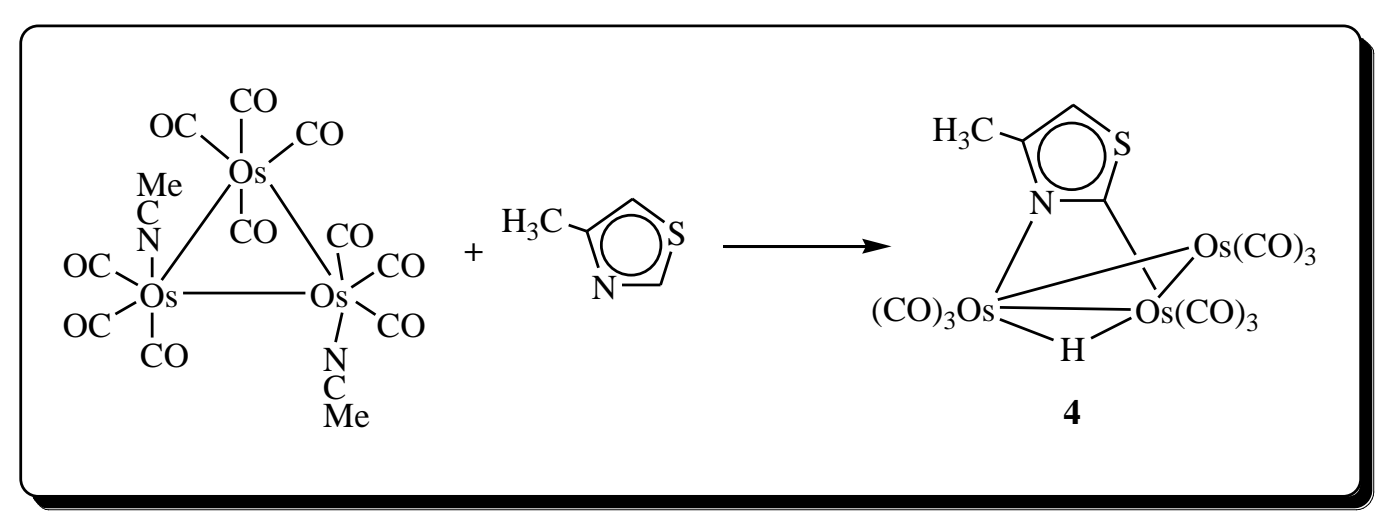

Scheme 4 
Studies on the interaction of rhenium carbonyls with both nitrogen and sulfur containing heterocycles are not well studied. Keeping these ideas in mind and as a continuation of our previous works on rhenium carbonyl chemistry we have decided to investigate the reaction of $\left.\mathrm{Re}_{2}(\mathrm{CO})_{8}(\mathrm{NCMe})_{2}\right]$ with 2-(methylmercapto)-benzothiazole / 2(methylmercapto)benzimidazole ligands.

\section{Results and Discussion}

Reaction of $\left[\operatorname{Re}_{2}(\mathrm{CO})_{8}(\mathrm{NCMe})_{2}\right]$ with 2-(methylmercapto)benzothiazole / 2methylmercapto-benzimidazole

The reaction of $\left[\mathrm{Re}_{2}(\mathrm{CO})_{8}(\mathrm{NCMe})_{2}\right]$ with ligand $\mathrm{L}=(2$-(methylmercapto) benzothiazole/ 2-methylmercaptobenzimidazole) in 1:2 molar ratio in refluxing benzene for 4 hours afforded the compound $\left[\operatorname{Re}_{2}(\mathrm{CO})_{8}\left(\mu-\eta^{1}, \eta^{1}-\left(\mathrm{C}_{7} \mathrm{H}_{4} \mathrm{NS}\right) \mathrm{SCH}_{3}\right]\right.$ 5a and $\left[\operatorname{Re}_{2}(\mathrm{CO})_{8}\left(\mu-\eta^{1}, \eta^{1}-\right.\right.$ $\left.\left(\mathrm{C}_{7} \mathrm{H}_{5} \mathrm{~N}_{2}\right) \mathrm{SCH}_{3}\right] 5 \mathrm{~b}$ respectively. (Scheme 5) as orange crystals in $28-30 \%$ yield. The compound has been characterized by IR, ${ }^{1} \mathrm{H}$ NMR and mass spectral data.

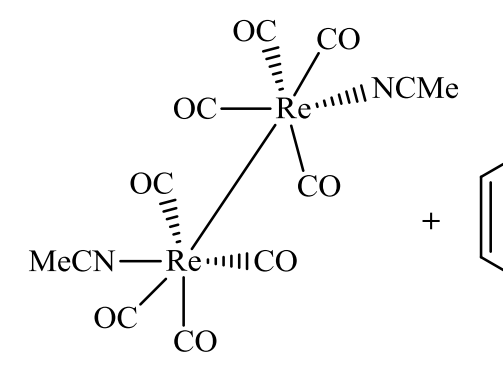<smiles>[X]c1nc2ccccc2[nH]1</smiles>

Benzene, $\frac{\text { Reflux } 4 \mathrm{hr}}{-2 \mathrm{MeCN}}$

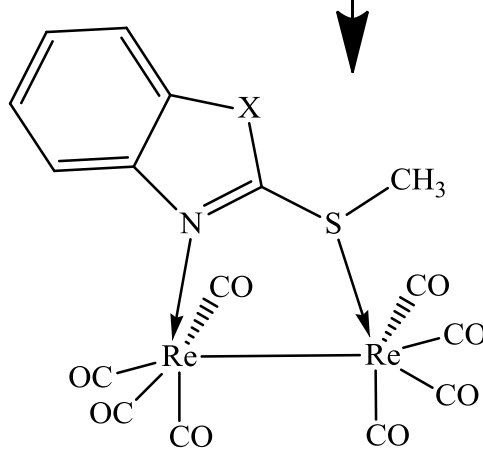

5a $X=S$

5b $\mathbf{X}=\mathbf{N H}$ 


\section{A plausible mechanism for the formation of the compound}

The compounds are believed to be formed simply by the displacement of the two acetonitrile ligands from $\left[\operatorname{Re}_{2}(\mathrm{CO})_{8}(\mathrm{NCMe})_{2}\right]$ which may occur in two general pathways (Scheme-6). One path A begins with the formation of Re-N bond by the substitution of

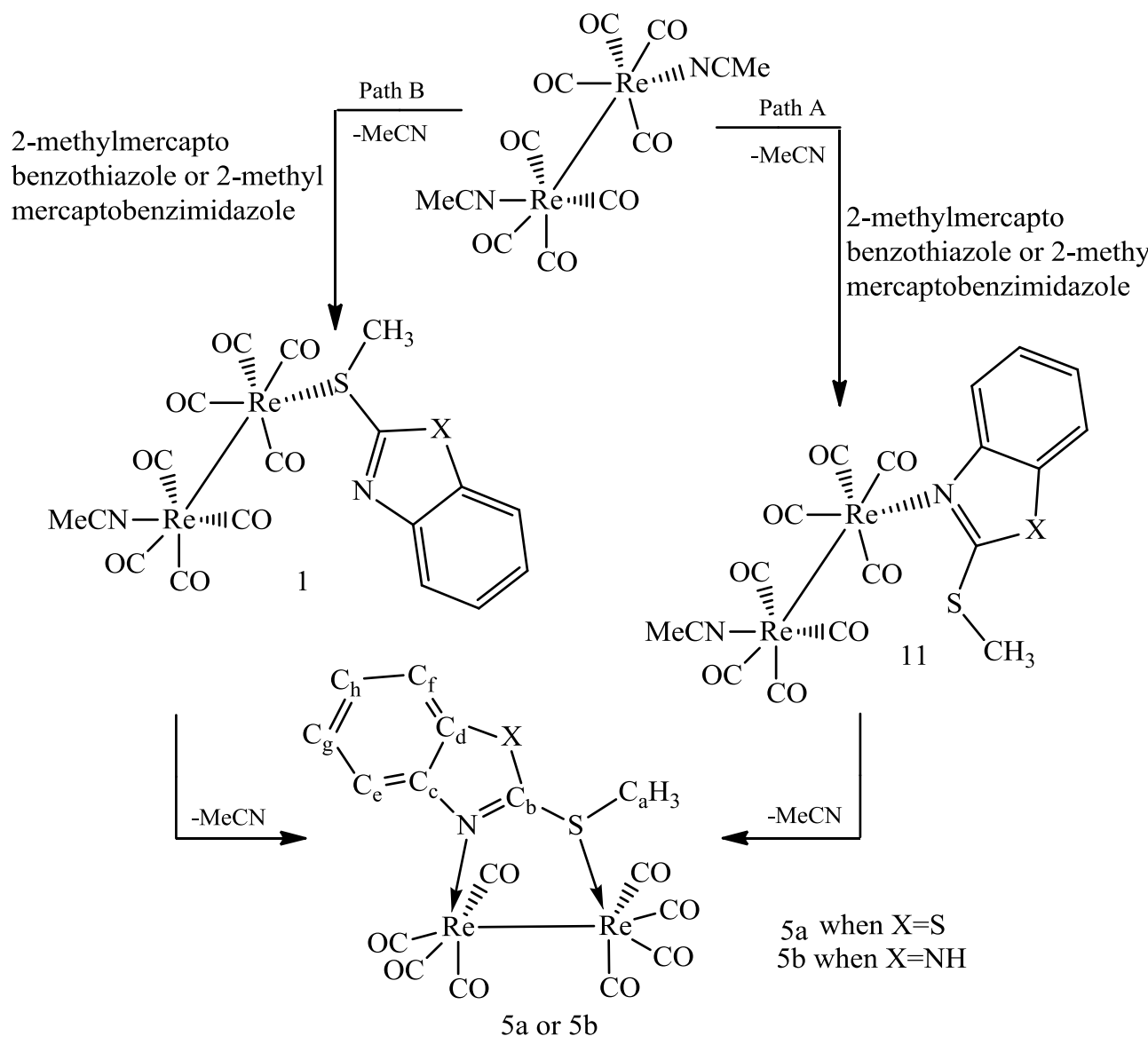

Scheme 6

an acetonitrile molecule. Pathway $B$ involves initial coordination of 2(methylmercapto)benzothiazole ligand through sulfur to Re atom by the displacement of 
an acetonitrile molecule. It may be assumed that the first step in pathway A occurs more rapidly than the first step in pathway B because of the small SMe group in 1 compared to the bulky benzothiazolyl group in II. However, our attempt of isolating such intermediates were unsuccessful for the rapid displacement of the second acetonitrile molecule. Moreover the $\mathrm{N}$ of the heterocycles gets preference than the sulfur due to rapid $\mathrm{C}-\mathrm{S}$ bond rotation at such higher temperature.

\section{Spectroscopic characterization of $\left[\operatorname{Re}_{2}(\mathrm{CO})_{8}\left\{\mu-\eta^{1}, \eta^{1}-\left(\mathrm{C}_{7} \mathrm{H}_{4} \mathrm{NS}\right) \quad \mathrm{SCH}_{3}\right\}\right] 5 \mathrm{a}$ and $\left[\operatorname{Re}_{2}(\mathrm{CO})_{8}\left\{\mu-\eta^{1}, \eta^{1}-\left(\mathrm{C}_{7} \mathrm{H}_{5} \mathrm{~N}_{2}\right) \mathrm{SCH}_{3}\right\}\right] 5 \mathrm{~b}$}

The compound 5a shows $v \mathrm{CO}$ absorption bands in $\mathrm{KBr}$ at 2074s, 2023s, 1938m and $1889 \mathrm{~m} \mathrm{~cm}^{-1}$. These are the characteristics of a typical dinuclear metal carbonyls. ${ }^{17}$

The ${ }^{1} \mathrm{H}$ NMR spectrum of the compound $\mathbf{5 a}$ in $\mathrm{CDCl}_{3}$ shows signals at $\delta 3.18(\mathrm{~s}, 3 \mathrm{H})$, $7.50\left(\mathrm{ddd}, 1 \mathrm{H},\left(\mathrm{H}_{2}\right.\right.$ or $\left.\left.\mathrm{H}_{3}\right) \mathrm{J}=8.0 \mathrm{~Hz}\right), 7.77\left(\mathrm{ddd}, 1 \mathrm{H},\left(\mathrm{H}_{2}\right.\right.$ or $\left.\left.\mathrm{H}_{3}\right), J=8.0,6.0,1.0 \mathrm{~Hz}\right), 7.83$ $\left(\mathrm{dd}, 1 \mathrm{H}, \mathrm{H}_{4}, J=8.0 \mathrm{~Hz}\right), 8.26\left(\mathrm{dd}, 1 \mathrm{H}, \mathrm{H}_{1}, J=8.0 \mathrm{~Hz}\right)$.

The mass spectrum of compound 5a shows the parent molecular ion peak at m/z 777 . Other important peaks at m/z $762\left(\mathrm{M}^{+}-\mathrm{CH}_{3}\right), 678\left(\mathrm{M}^{+}-\mathrm{CH}_{3}-3 \mathrm{CO}\right), 553\left(\mathrm{M}^{+}-8 \mathrm{CO}\right), 452$ $\left(\mathrm{M}^{+}-\mathrm{Re}-5 \mathrm{CO}\right)$ are observed.

The compound $\left[\operatorname{Re}_{2}(\mathrm{CO})_{8}\left\{\mu-\eta^{1}, \eta^{1}-\left(\mathrm{C}_{7} \mathrm{H}_{5} \mathrm{~N}_{2}\right) \mathrm{SCH}_{3}\right\}\right] \mathbf{5 b}$ shows $v \mathrm{CO}$ absorption bands in $\mathrm{KBr}$ at 2090s, 2030s, $1920 \mathrm{~m}$ and $1850 \mathrm{~m} \mathrm{~cm}^{-1}$. These are the characteristics of a typical dinuclear metal carbonyls. ${ }^{17}$ The ${ }^{1} \mathrm{H}$ NMR spectrum of the compound $\mathbf{5 b}$ in $\mathrm{CDCl}_{3}$ shows signals at $\delta 3.05(\mathrm{~s}, 3 \mathrm{H}), 7.76\left(\mathrm{ddd}, 1 \mathrm{H},\left(\mathrm{H}_{2}\right.\right.$ or $\left.\left.\mathrm{H}_{3}\right) \mathrm{J}=8.0 \mathrm{~Hz}\right), 7.44\left(\mathrm{ddd}, 1 \mathrm{H},\left(\mathrm{H}_{2}\right.\right.$ or $\left.\mathrm{H}_{3}\right)$, $J=8.0,6.0,1.0 \mathrm{~Hz}), 7.33\left(\mathrm{dd}, 1 \mathrm{H}, \mathrm{H}_{4}, J=8.0 \mathrm{~Hz}\right), 8.14\left(\mathrm{dd}, 1 \mathrm{H}, \mathrm{H}_{1}, J=8.0 \mathrm{~Hz}\right) .12 .2$ (s, broad, $1 \mathrm{H}, \mathrm{NH})$.

${ }^{13} \mathrm{C} \mathrm{NMR}$ spectrum of $\mathbf{5 b}$ in $\mathrm{CDCl}_{3}$ shows signals at $\delta 34.24,77.52,111.7,120.7,125.7$, $125.9,133,144.3,165.19,190.39,195,204.54 \mathrm{ppm}$. The signal at $\delta 34.24$ is due to the $\mathrm{CH}_{3}$ carbon $\left(\mathrm{C}_{\mathrm{a}}\right)$. The signal at $\delta 77.52$ is due to the $\mathrm{CDCl}_{3}$ (Solvent). The signals at $\delta$ 111.7, 120.7, 125.7, 125.9,133, 144.3, are due to the benzene ring carbons $\left(\mathrm{C}_{\mathrm{c}}, \mathrm{C}_{\mathrm{d}}, \mathrm{C}_{\mathrm{e}}, \mathrm{C}_{\mathrm{f}}\right.$, $\mathrm{C}_{\mathrm{g}}, \mathrm{C}_{\mathrm{h}}$ ). The signal at $\delta 165$ is due to the $\mathrm{C}_{\mathrm{b}}$ carbon atom which lie between two $\mathrm{N}$ atoms. The signals at $\delta 190.39,195$ and 204.54 are due to the carbonyl carbon atom.

The mass spectrum of compound $\mathbf{5 b}$ shows the parent molecular ion peak at $\mathrm{m} / \mathrm{z} 760$. Other important peaks at m/z $745\left(\mathrm{M}^{+}-\mathrm{CH}_{3}\right), 660\left(\mathrm{M}^{+}-\left(\mathrm{CH}_{3}+3 \mathrm{CO}\right), 619\left(\mathrm{M}^{+}-5 \mathrm{CO}\right), 535\right.$ $\left(\mathrm{M}^{+}-8 \mathrm{CO}\right)$ and 164 base peak which corresponds to the ligand.

The exact bonding mode of the ligand could not be ascertained without the X-ray crystal structure determination. It is proposed from the IR, NMR and Mass spectral data that the molecules consist of a dirhenium core with eight terminal carbonyl ligands and a four electron donor 2-(methylmercapto)benzothiazole and 2-(methylmercapto)benzimidazole 
ligand respectively. An interesting structural feature of the compound is the coordination of the ligand L (2-methylmercapto)benzothiazole and 2-(methylmercapto)benzimidazole) in a $\mu-\eta^{1}, \eta^{1}$ - fashion to one Re atom through the nitrogen and other Re atom through the sulfur atom. Each rhenium atom attains a slightly distorted octahedral arrangement through the terminal carbonyl ligands and the organic moiety. The molecule is electron precise with one metal-metal bond and obeys the 18 electron rule.

\section{Experimental}

\section{General remarks}

All the reactions were carried out under a dry nitrogen atmosphere using standard Schlenk techniques. Solvents were purified and distilled from the appropriate drying agents and stored under nitrogen prior to use. Products were separated by thin layer chromatography (TLC) on silica gel (type-60) $\mathrm{GF}_{254}$ Merck 7730 in air. Infrared spectra were recorded on a Shimadzu FTIR 8101 spectrophotometer. ${ }^{1} \mathrm{H}$ NMR and ${ }^{13} \mathrm{C}$ NMR spectra were recorded on a Bruker DPX 400 spectrometer. The chemical shifts were referenced to the residual solvent proton resonances $\left(\delta=7.24 \mathrm{ppm}\right.$ for $\left.\mathrm{CHCl}_{3}\right)$. Mass spectra were recorded on a varian MATC7H instrument (direct injection, electron impact ionization 70ev). The compound $\left[\operatorname{Re}_{2}(\mathrm{CO})_{10}(\mathrm{MeCN})_{2}\right]$ was prepared according to the known procedure. 2-(methylmercapto)benzothiazole and 2-(methylmercapto) benzimidazole were purchased from Adrich chemical company and used as received.

\section{Preparation of $\left[\operatorname{Re}_{2}(\mathrm{CO})_{8}(\mathrm{MeCN})_{2}\right]$}

A three necked round bottom flask equipped with a pressure-equalizing dropping funnel was flushed with nitrogen and charged with $\left[\mathrm{Re}_{2}(\mathrm{CO})_{10}\right](1.0 \mathrm{~g}, 1.5 \mathrm{mmol}), \mathrm{CH}_{2} \mathrm{Cl}_{2}(10$ $\left.\mathrm{cm}^{3}\right)$ and $\mathrm{MeCN}\left(10 \mathrm{~cm}^{3}\right), \mathrm{Me}_{3} \mathrm{NO}(0.23 \mathrm{~g}, 3.0 \mathrm{mmol})$ in $\mathrm{CH}_{2} \mathrm{Cl}_{2}\left(5 \mathrm{~cm}^{3}\right)$ was added drop wise over $1 \mathrm{~h}$ and the reaction mixture stirred at room temperature until complete conversion was occurred (22-24h, monitored by analytical TLC). Evaporation of the solvent and recrystallization from $\mathrm{CH}_{2} \mathrm{Cl}_{2}$ / hexane containing a few drop of $\mathrm{MeCN}$ gave pure $\left[\mathrm{Re}_{2}(\mathrm{CO})_{8}(\mathrm{MeCN})_{2}\right](0.08 \mathrm{~g}, 80 \%)$ as yellow crystals. ${ }^{18}$

\section{Reaction of $\left[\operatorname{Re}(\mathrm{CO})_{8}(\mathrm{MeCN})_{2}\right]$ with ligand $\mathrm{L} \quad(\mathrm{L}=2$-(methylmercapto)- benzothiazole / 2-(methylmercapto)-benzimidazole}

A dry nitrogen flushed $100 \mathrm{ml}$ three-necked flask was equipped with a magnetic bar, thermometer, rubber septum and a reflux condenser. A solution of $\left[\operatorname{Re}_{2}(\mathrm{CO})_{8}(\mathrm{MeCN})_{2}\right]$ $(0.02 \mathrm{~g}, 0.29 \mathrm{mmol})$, and ligand $\mathrm{L}(0.59 \mathrm{mmol})$ in freshly distilled benzene $\left(30 \mathrm{~cm}^{3}\right)$, was heated to $80^{\circ} \mathrm{C}$ in an oil bath and refluxed for 4 hours with continuous stirring. The colour of the reaction mixture changed from yellow to orange. The solvent was removed under vacuum and the residue separated by TLC $\left[\mathrm{SiO}_{2}\right.$; eluant: cyclohexane- 
dichloromethane $(7: 3, \mathrm{v} / \mathrm{v})]$ to give the compounds $\left[\mathrm{Re}_{2}(\mathrm{CO})_{8}\left\{\mu-\eta^{1}, \eta^{1}-\left(\mathrm{C}_{7} \mathrm{H}_{4} \mathrm{NS}\right) \mathrm{SCH}_{3}\right\}\right]$ $5 \mathrm{a}(0.056 \mathrm{~g}, 28 \%)$ as orange and $\left[\mathrm{Re}_{2}(\mathrm{CO})_{8}\left(\mu-\eta^{1}, \eta^{1}-\left(\mathrm{C}_{7} \mathrm{H}_{5} \mathrm{~N}_{2}\right) \mathrm{SCH}_{3}\right] 5 \mathrm{~b}(0.067 \mathrm{~g}, 30 \%)\right.$ as lemon yellow crystals from $n$-hexane $/ \mathrm{CH}_{2} \mathrm{Cl}_{2}$ mixture at room temperature.

\section{Acknowledgement}

The authors acknowledge Jahangirnagar Univrersity for financial assistance. Special thanks to Prof. H.G. Alt (university of Bayreuth, Germany) for providing the mass spectra of the compounds.

\section{References}

1. (a) R. A. Mchado; M. C. Goite; D. Rivillo; Y. De Sanctis; A. J. Arce; A. J. Deeming; L. D Orneals; A sierralta; R. Atencio; T. Gonzalez and E. J. Galarza, J. Organomet. Chem. 2007, 692, 894. (b) R. A. Machado, D. Rivillo, A. J. Arce, L. D Ornellam Y. De Sanctis, R. Atencio, T. Gonzalez and E. Galarza, J. Organomet. Chem 2004, 689, 2486. (c) J. Reedjik; in: G. Wilkinson, R. D. Gillard, J. A McClaverty (Eds). Comprehensive coordination Chemistry, vol 2 Pergamon press Oxford, 1987, p73. (d) M. A. Reynolds, I. A. Guzei, R. J. Angelici, Organometallics, 2001, 20, 1071. (e) M. A .Reynolds, I. A. Guzei, R. J. Angelici, J. Chem. Commun. 2001, 513. (f) R. J. Angelici, Polyhedron.1997, 16, 3073. (g) M. A. Ruben, A. J. Arce, Y. De Sanctis, A. J. Deeming and L. D. Orneals, J. Organomet.Chem. 2005, 690, 622 .

2. (a) J. D. Peterson, W. R. Murphey, R. Sahai, K. J. Brewer and R. R. Rumenski, Coord. Chem. Rev., 1985, 261, 64. (b) Ch. Jiang, T. S. A. Hor, Y. K. Yan, W. Henderson, and L. J. McCaffrey, J. Chem. Soc., Dalton Trans., 2000, 3204.

3. (a) H. J. Haupt, P. Balsaa, and U. Florke, Z. Anorg. Allg. Chem., 1987, 548, 151.

(b) H. J. Haupt, O. Krampe, and U. Florke, Z. Anorg. Allg. Chem., 1996, 622, 151.

4. (a) J. Grobe and W. Mohr, J. Fluorine Chem., 1976, 8, 145. (b) R. D. Adams and J. D. Kuhns, Polyhedron, 1988, 7, 2543. (c) G. Ciani, G. D'Alfonso, P. Romoti, A. Sironi and M. Freni, Inorg. Chem. 1983, 22, 3115.

5. (a) P. O. Nubel, S. R. Wilson and T. L. Brown, Organometallics, 1983, 2, 515.

(b) V. Gard and T. L. Brown, Organometallics, 1982, 1, 1143.

6. S. Top, M. Gunn, G. Joen. J. Vaissermann, J.C. Daran and R.J. Thornback, J. Organomet. Chem., 1991, 414, C22.

7. P. O. Nubel and T. L. Brown, J. Amer. Chem. Soc., 1984, 106, 644.

8. C. G. Kreiter, K. H. Franzreb and W.S. Sheldrick, J. Organomet. Chem., 1984, 270, 71.

9. H. Egold, V. Schwarze and U. Florke, J. Chem. Soc. Dalton Trans., 1999, 3203.

10. (a) Y. K. Au, K .K. Cheung and W. T. Wong, Inorg. Chim. Acta, 1995, 228, 267. (b) Y. K. Au, K. K. Cheung and W. T. Wong, J. Chem. Soc. Dalton Trans. 1995, 1047. (c) A. J. Deeming, M. Karim and K. I. Hardcastle, Inorg. Chem., 1991, 31, 4792 (d) A. J. Deeming, M. Karim, N.I. Powell and K. I. Hardcastle, Polyhedron, 1990, 9, 623. 4792 (e) A. M. Brodie, H. D. Holden, J. Lewis and M. J. Taylor, J. Chem. Soc. Dalton Trans. 1986, 4792. 
11. R. Dilshad, K. H. Hanif, M. B. Hursthouse, S. E. Kabir, K. M. A. Malik and E. Rosenberg, J. Organomet. Chem., 1999, 588, 100

12. K. H. Hanif, M. B.Hursthouse, S. E. Kabir, K. M. A. Malik and E. Rosenberg, J. Organomet. Chem., 1999, 580, 60

13. K. A. Azam, R. Dilshad, S. E. Kabir, K. Khatoon, L. Nissa, M. M. Rahman E. Rosenberg, M. B.Hursthouse, K. M. A. Malik and A. J. Deeming, J. Chem. Soc. Dalton Trans. 1996, 1731.

14. K. A. Azam, S. A. Hussain, S. E. Kabir, M. M. Rahman, M. B.Hursthouse, K. M. A. Malik and E. Rosenberg, J. Organomet. Chem., 1998, 559. 81.

15. K. A. Azam, M. B.Hursthouse, S. E. Kabir, K. M. A. Malik, M. Tesmer and H. Vahrenkamp, Inorg. Chem. Commun., 1998, 1, 402

16. M. R. Churchill, K. N. Amoh and H. Wasserman, J. Inorg. Chem., 1981, 20, 1609.

17. F. A. Cotton, and G. Wilkinson, Basic Inorganic Chemistry, Wiley Eastern Limited, 1986, Chapter 28.

18. M. I. Bruce, P. J. Jao, J. Organomet. Chem., 1996, 519. 221. 